\title{
Why Culture Matters in Business Research
}

\author{
Gene E. Fusch \\ Walden University \\ Christina J. Fusch \\ Walden University \\ Janet M. Booker \\ Walden University \\ Patricia I. Fusch \\ Walden University
}

\begin{abstract}
Organizations today are changing rapidly due to technology, globalization, and cutting-edge production, subsequently morphing into new structures and workflow processes.

Organizations are becoming more diverse in terms of gender, age, race, ethnicity, veteran status, sexual orientation, and others. The business workplace is not the melting pot that many were taught about, but that of the ethnic salad, blended yet distinct. The core of organizational composition worldwide still remains within the human resource realm for a shared and cohesive culture is behind the success of every company. The study of workplace culture is important for business research to ascertain the construct of the successful organization. The article begins with a discussion about culture, relates culture to the workplace, and ends relating important business research to workplace culture. The intended audience is business management majors and instructors.
\end{abstract}

Keywords: culture, ethnography, organizational success, productivity and performance, business research

\section{Introduction}

Why does culture matter, or, more importantly, what is culture? In the Middle East, archaeologists search for ancient cultures in giant hills of dirt called tells, derived from the Arabic word for hill (AlNahar, 2010). This is one way to think of culture. Think of lives as hills of culture: holistic, integrated, learned, linguistic, and shared (C. J. Fusch, 2014). Culture is holistic, all inclusive. Everything in one's life, whether it be the economy, the workplace, family, religion, hobbies, table manners, or education, makes up one's culture (Botz-Bornstein, 2012). Culture is the way in which each interacts with another, a set of rules for beliefs and behavior that all follow to be members of society (Botz-Bornstein, 2012). Business related to cultural theory is "unlike studying culture in well-defined communities, organizational scholars study its assumptions and beliefs alongside strategies, structures, control systems, technologies, and business models" (Murphy, Cooke, \& Lopez, 2013, p. 662). 
Culture is integrated, with each element connected and influencing another (Abdollahi-Guilani, Yasin, Hua, \& Agahaei, 2012). One cannot isolate certain aspects of a culture without producing a distorted viewpoint (Abdollahi-Guilani et al., 2012). These aspects are interlinked, directly impacting one another to create the current situation (Abdollahi-Guilani et al, 2012). Culture is learned; in fact, it must be learned. It is not biological. For example, eating is necessary to live, but how and what one eats may be determined by one's culture (C. J. Fusch, 2014). Religious sanctions on certain types of food in the Middle East best represent the learned nature of a culture (Ambail \& Bakar,

2013). These food restrictions are not self-evident, rather they must be taught in order to be followed (Ambail \& Bakar, 2013).

Culture is shared; for a belief or behavior to be considered cultural, it must be shared (Harris, Mayo, Prince, \& Tooey, 2013). It must be considered appropriate by the society to be a custom (Nnadi, 2013). Language is one of the most obviously shared elements of a culture (Abdollahi-Guilani et al., 2012). Along with shared history, language is often used to define what scholars consider a culture (Abdollahi-Guilani et al., 2012; C. J. Fusch, 2014). In this sense, culture is also linguistic (C. J. Fusch, 2014).

So then, to take one back to the original question, why does culture matter in business research? An anthropological answer would be because culture defines everything that one is from childhood to elderly age and it encompasses all one does and tries to do (C. J. Fusch, 2014). All breathe in a biological system, but one must live in a cultural context so one knows what to do beyond the biological necessities of eating and sleeping (C. J. Fusch, 2014). Indeed, whether from the Tells of ancient civilizations to the modern business world of today, culture is human interaction (C. J. Fusch, 2014) and the core of every business is within the human resource realm.

\section{History of Culture in the Workplace}

Globalization has a profound impact on today's leader and the workplace (Weadick, 2005). The leader must adapt management style, roles, duties, and strategies (Kumar, Anjum, \& Sinha, 2011; Matviuk, 2010; Müller, Spang, \& Ozcan, 2008; Seah, Hsieh, \& Huang, 2014) in order to work with diverse peoples of cultures other than his or her own (Jyh-Shen, \& Tung-Zong, 2009; Prewitt, Weil, \& McClure, 2011; Rockstuhl, Dulebohn, Ang, \& Shore, 2012; Sultana, 2013). The workplace may be in the leader's own country, or the leader may be transferred elsewhere in the world to work (Littrell, 2013). The leader must also deal with post-9/11 concerns with safety and security, as well as anticapitalism backlash in addition to the outsourcing of essential jobs (Deitchman, 2013).

At the turn of the 20th century, managerial skills were based upon the functional approach, wherein performance was based upon the achievement of set goals (G. E. Fusch \& Gillespie, 2012; Godfrey \& Mahoney, 2014). Therefore, it was the manager's responsibility to monitor the attainment of the set goals, as well as correct methods and procedures as needed to reach those goals (Godfrey \& Mahoney, 2014). Researchers such as Frederick Taylor, Henry Mintzberg, and Henri Fayol appeared to be more focused on the task at hand, rather than the persons performing the tasks (G. Fusch, 2001); therefore, workplace culture did not necessarily matter. The research of Robert Katz as well as Fred Luthans emphasized the human resource dimension of management, recognizing that some of the best managers of the functional approach may be competent on the technical end, yet unable to achieve organizational goals through inability to motivate people (Peterson \& Van Fleet, 2004).

Indeed, organizational behavior is an applied behavioral science that utilizes and combines other disciplines into a model effective for the understanding of organizations (Babcock-Roberson \& Strickland, 2010; Down, 2012). The field of anthropology has been referred to as the forgotten science 
of behavioral studies due to factors specific to this discipline (Morey \& Luthans, 2013). Anthropology may be perceived as an inexact science with no formal rules, a combination of art and science, due to its emphasis on ethnography (Bernard, 2011). The anthropologist becomes the participant/observer in the native culture, looking out from the native eyes, to study and better understand humans and human activity (Lavenda \& Schultz, 2010). Particular attention is paid to observing and interacting using qualitative methods as opposed to using quantitative statistical models in other disciplines (Jackson, 1990).

Perhaps anthropology's greatest contribution to organizational behavior is its emphasis on the ability to facilitate understanding between peoples in other countries or organizations (Down, 2012; Lavenda \& Schultz, 2010). This learning about cultures is accomplished by noting differences in values, attitudes, and behavior (Lavenda \& Schultz, 2010). Rather than focusing on the individual, as in other disciplines, the focus here is on the macro level, as in group processes and organization (Anand, 2013). This cultural understanding is particularly important in today's workplace as people and organizations learn to manage diversity and globalization, whether one is assigned to another country or becomes a member of a virtual team (Daim et al., 2012).

\section{The Cultural Context of Leadership and Management: Managing Across Timelines, Continents, and Culture}

In the contemporary business environment, company leaders face continual change that can hamper attempts to remain profitable (Dekkers, 2011). Organizational leader attempts at mergers and reengineering attempts often fail, consultants are of little help, and strategic planning is ineffective (Boniface \& Rashmi, 2012). Management and leadership lack adequate understanding of problems and their solutions because they cannot see the issues, are unaware of choices and alternatives, and lack the skill to implement a correction (Bolman \& Deal, 2013). When companies become more flexible and fluid, the company leaders are able to respond to an ever-fluctuating business environment (Dominici \& Palumbo, 2013). These challenges encompass rapid technological change, the pressure of the competitive marketplace, rising production costs, cutting-edge alterations, scarcity of resource input, changing worker needs and demands, increasing operational costs and potential taxes, and intensifying governmental regulations regarding health care (Laroche \& Wechtler, 2011; Meadors, 2010; Söderholm \& Norrbin, 2013).

Organizational behavior now has a global face. Organizational leaders need to personify the different values of cultures in different countries, in order to be effective (Sultana, Rashid, Mohiuddin, \& Hudam, 2013). Globalization was perhaps the most frequently used buzz word of the 1990s (Weadick, 2005). The word is still popular today and often misused by most, its definition used to describe whatever the user wishes it to mean, whether positive or negative (Weadick, 2005). The descriptive term globalization has also been used in place of international and multicultural, as well as transnational (Cristian \& Raluca, 2010). Its definition over time has become so muddled as to facilitate the pejorative term globaloney (Lutz, 1989), a word coined by Representative Clare Boothe Luce in her inaugural speech to Congress in 1943.

Transglobal companies now reflect the increasing diversity of the workforce rather than representing a host country (Brimhall, Lizano, \& Mor Barak, 2014). Furthermore, organizational culture now has a greater impact on productivity than national culture, as workers adapt to a workplace that transcends their nationality (Uddin, Luva, \& Hossian, 2013). This is posited to have an impact on managerial practices for the future as management actively seeks to "create, maintain, and change the organizational culture" (Naor, Linderman, \& Schroeder, 2010, p. 195). 
To be sure, leaders in contemporary multicultural organizations must master context to understand culture (Bennis, 2009) while managing and leading in an environment where there are no common definitions of efficient outcome or effectiveness. It is imperative that organizations address cultural differences when managing diverse work forces (Brimhall et al., 2014). Symbolic assumptions are not what happens but what it means, events have multiple meanings, and people create meanings (Barrett, 2012). Moreover, "[c]ulture is the glue that holds an organization together and unites people around shared values and beliefs...the interwoven patterns of beliefs, values, practices, and artifacts that defines for members who they are and how they are to do things" (Bolman \& Deal, 2003, p. 243). Culture has a specialized language, a history, values, shared identity, ritual, and ceremony (C. J. Fusch, 2014). It is important to find the meaning, for “. . . human actions cannot be understood unless the meaning that humans assign to them is understood" (Marshall \& Rossman, 2016, p. 101). Furthermore, the world is made of multiple realities rather than a static state; therefore, all realities are relevant and valid (Elanain, 2013; Erlingsson \& Brysiewicz, 2013).

\section{Research Regarding Culture in the Workplace}

Booker (2011) noted that ethnographic researchers explore a culture from the views of those on the inside of the culture. Corporate ethnographers use ". . . technical reports, powerpoint presentations, workshops, diagnostic exercises, video presentations, etc." (Fayard \& Van Maanen, 2015, p. 6) to present findings. In the same respect, leaders could internally analyze what is working in their culture and what is not in an effort to build a work culture that supports the objectives of the organization (G. E. Fusch, 2001; P. I. Fusch \& Fusch, 2015; Hodson, 2008). One distinctive strategy for business leaders to follow might be to focus on what type of culture makes an organization "succeed instead of fail" (Booker, 2011, p. 105). The motivators that subcultures create can lead to an increase in organizational performance (Booker, 2011). The significance to business leadership may be to examine the subcultures they "could apply to the population of workers they are attempting to motivate, which could include the importance of continued job training" (p. 106), and winning the approval of others such as a boss, coworkers, or family members (Booker, 2011). Leaders need to know what to build into their culture to help implement change tactics into existing programs to produce the desired results for the organization (G. E. Fusch, 2001). Workers want to feel they have worth and understanding and it is their work culture that can breed a sense of satisfaction into their daily tasks (P. I. Fusch \& Fusch, 2015; Yafang, 2011). To be sure, in terms of business research, the use of an ethnographic design and of cultural perspective demonstrates the importance of the study (Freeman \& Spanjaard, 2012; Gordon, 2011).

G. E. Fusch (2001) found that in a culture where leadership promoted and demonstrated validation and valuing behaviors, workers wanted to go to work in the morning and endeavored to help the company succeed. In contrast, a rapidly changing workplace environment where workers feel out of control, unaware of the changes, and sometimes afraid can lead to reluctance to the interest of the organization (Palombo, 2013). In Palombo's (2013) mini-ethnographic study, he found strategies the leader in one small machine shop used to improve the workplace culture while overcoming resistance to change. From a research perspective, the importance of studying the culture enables one to look at the interactions in the workplace for "although we cannot see attitudes, we can see working behavior" (G. E. Fusch \& Gillespie, 2012, p. 94). Every workplace has a specific culture and ethnographic research enables the researcher to understand that culture. 


\section{Conclusion}

The diversity of the workforce impacts the leader of today. Organizations are becoming more diverse in terms of gender, age, race, ethnicity, and sexual orientation (Robbins \& Judge, 2014). These differences are those among people within a given country and include such categories as gender, age, race, ethnicity, veteran status, sexual orientation and others. Indeed, the organization today is not the melting pot that many were taught in public school, but that of the ethnic salad, blended yet distinct. Moreover, culture must be socially acceptable and consistent with needs and values. Organizations are composed of people who get the job done, united by a common workplace culture (Bolman \& Deal, 2013), for a shared and cohesive culture is behind the success of every company.

The core of organizational composition remains in the human resource realm, where needs and wants remain basically the same as they have always been, for meaningful, creative work, and recognition and reward in the workplace (Bolman \& Deal, 2013). Indeed, organizations today are changing rapidly due to technology, globalization, and cutting-edge production, subsequently morphing into new structures and workflow processes (Narasimhan, Krull, \& Nahm, 2012; Voegtlin, Patzer, \& Scherer, 2012). A common culture in the workplace is essential for business success (Booker, 2011; G. Fusch, 2001; P. I. Fusch \& Fusch, 2015); therefore, the study of workplace culture is important for business research.

\section{References}

Abdollahi-Guilani, M., Yasin, M. S. M., Hua, T. K., \& Agahaei, K. (2012). Culture-integrated teaching for the enhancement of EFL learner tolerance. Asian Social Science, 8, 115-120. Retrieved from http://ccsenet.org/journal/index.php/ass/article/view/16543

Al-Nahar, M. (2010). Tell Abu Suwwan, A neolithic site in Jordan: Preliminary report on the 2005 and 2006 field seasons. Bulletin of the American Schools of Oriental Research, 357, 1-18. Retrieved from http://www.asor.org/pubs/basor/_baks/357.pdf.0001.b0e0.bak

Ambail, A. R., \& Bakar, A. N. (2013). Halal food and products in Malaysia: People's awareness and policy implications. Intellectual Discourse, 21, 7-32. Retrieved from http://journals.iium.edu.my/intdiscourse/index.php/islam/article/view/504

Anand, V. (2013). Organizational behavior: A conceptual study required for organization performance and existence. International Journal of Organizational Behaviour and Management Perspectives, 2, 629-633.

Babcock-Roberson, M., \& Strickland, O. J. (2010). The relationship between charismatic leadership, work engagement, and organizational citizenship behaviors. Journal of Psychology, 144, 313-326. Retrieved from http://www.tandfonline.com/toc/vjrl20/current

Barrett, L. F. (2012). Emotions are real. Emotion, 12, 413-429. doi:10.1037/a0027555

Bennis, W. (2009). On becoming a leader (4th ed.). New York, NY: Basic.

Bernard, R. H. (2011). Research methods in anthropology: Qualitative and quantitative approaches. Thousand Oaks, CA: Sage.

Bolman, L. G., \& Deal, T. E. (2003). Reframing organizations: Artistry, choice, and leadership (3rd ed.). San Francisco, CA: Jossey-Bass. 
Bolman, L. G., \& Deal, T. E. (2013). Reframing organizations: Artistry, choice, and leadership (5th ed.). San Francisco, CA: Jossey-Bass.

Boniface, M., \& Rashmi, M. (2012). Outsourcing: Mass layoffs and displaced workers' experiences. Management Research Review, 35, 1029-1045. doi:10.1108/01409171211276927

Booker, J. M. (2011). A descriptive analysis of high school student motivators for success (Doctoral dissertation). Retrieved from ProQuest Dissertations \& Theses database. (UMI No. 3471687)

Botz-Bornstein, T. (2012). What is the difference between culture and civilization? Two hundred fifty years of confusion. Comparative Civilizations Review, 66, 10-28.

Brimhall, K. C., Lizano, E. L., \& Mor Barak, M. E. (2014). The mediating role of inclusion: A longitudinal study of the effects of leader-member exchange and diversity climate on job satisfaction and intention to leave among child welfare workers. Children and Youth Services Review, 40, 79-88. doi:10.1016/j.childyouth.2014.03.003

Cristian, S., \& Raluca, I. O. (2010). Beyond the borders of globalization EU-Africa, economy and conflict. Annales Universitatis Apulensis: Series Oeconomica, 12, 589-593.

Daim, T. U., Ha, A., Reutiman, S., Hughes, B., Pathak, U., Bynum, W., \& Bhatla, A. (2012). Exploring the communication breakdown in global virtual teams, International Journal of Project Management, 30, 199-212. doi:10.1016/j.ijproman.2011.06.004

Deitchman, S. (2013). Enhancing crisis leadership in public health emergencies. Disaster Medicine and Public Health Preparedness, 7, 534-540. doi:10.1017/dmp.2013.81

Dekkers, R. (2011). Impact of strategic decision making for outsourcing on managing manufacturing. International Journal of Operations \& Production Management, 31, 935-965. doi:10.1108/01443571111165839

Dominici, G., \& Palumbo, F. (2013). Decoding the Japanese lean production system according to a viable systems perspective. Systemic Practice \& Action Research, 26, 153-171. doi:10.1007/s11213-012-9242-z

Down, S. (2012). A historiographical account of workplace and organizational ethnography. Journal of Organizational Ethnography, 1, 72-82. doi:10.1108/20466741211220679

Elanain, H. M. A. (2013). Examining the relationship between leader-member exchange and subordinate outcomes: The mediating effects of role clarity. A study from an Arabic cultural context. Journal of Applied Management and Entrepreneurship, 18, 76-96. Retrieved from http://www.huizenga.nova.edu/Jame/

Erlingsson, C., \& Brysiewicz, P. (2013). Orientation among multiple truths: An introduction to qualitative research. African Journal of Emergency Medicine, 3, 92-99. doi:10.1016/j.afjem.2012.04.005

Fayard, A., \& Van Maanen, J. (2015). Making culture visible: Reflections on corporate ethnography. Journal of Organizational Ethnography, 4, 4-27. doi:10.1108/JOE-12-2014-0040

Freeman, L., \& Spanjaard, D. (2012). Bridging the gap: The case for expanding ethnographic techniques in the marketing research curriculum. Journal of Marketing Education, 34, 238250. doi:10.1177/0273475312455334

Fusch, C. J. (2014). Why culture matters: An anthropological approach to our lives. Humanities Washington. Retrieved from http://www.humanities.org/programs/speakers/currentspeakers/christina_fusch 
Fusch, G. E. (2001). Work/Life and the workplace: An ethnographic case study of a high-performance working environment (Doctoral dissertation). Available from Proquest Dissertations and Theses database. (UMI No. 3030899)

Fusch, G. E., \& Gillespie, R. C. (2012). A practical approach to performance interventions and analysis. 50 models for building a high-performance culture. Upper Saddle River, NJ: Finance Times Press

Fusch, P. I., \& Fusch, G. E. (2015). Leadership and conflict resolution on the production line. International Journal of Applied Management and Technology, 14, 21-39. doi:10.5590/IJAMT.2015.14.1.02

Godfrey, P. C., \& Mahoney, J. T. (2014, April 22). The functions of the executive at 75: An invitation to reconsider a timeless classic. Journal of Management Inquiry, 23, 360-372. doi:10.1177/1056492614530042

Gordon, W. (2011). Behavioral economics and qualitative research-a marriage made in heaven? International Journal of Market Research, 53, 171-185. doi:10.2501/IJMR-53-2-171-186

Harris, R., Mayo, A., Prince, J. D., \& Tooey, M. J. (2013). Creating shared campus experiences: The library as culture club. Journal of the Medical Library Association, 101, 254-256.

Hodson, R. (2008). The ethnographic contribution to understanding co-worker relations. British Journal of Industrial Relations, 46, 169-192. doi:10.1111/j.1467-8543.2007.00670.x

Jackson, J. E. (1990). I am a fieldnote: Fieldnotes as a symbol of professional identity. In R. Sanjek (Ed.), Fieldnotes: The making of anthropology (pp. 3-33). Ithaca, NY: Cornell University Press.

Jyh-Shen, C., \& Tung-Zong, C. (2009). The effect of management leadership style on marketing orientation, service quality, and financial results: A cross-cultural study. Journal of Global Marketing, 22, 95-107. doi:10.1080/08911760902767961

Kumar, R., Anjum, B., \& Sinha, A. (2011). Cross-cultural interactions and leadership behaviour. Researchers World: Journal of Arts, Science \& Commerce, 2, 151-160.

Laroche, P., \& Wechtler, H. (2011). The effects of labor unions on workplace performance: New evidence from France. Journal of Labor Research, 32, 157-180. doi:10.1007/s12122-011-91069

Lavenda, R. H., \& Schultz, E. A. (2010). Core concepts in cultural anthropology (4th ed.). New York, NY: McGraw-Hill.

Littrell, R. F. (2013). Explicit leader behavior: A review of literature, theory development, and research project results. Journal of Management Development, 32, 567-605. doi:10.1108/JMD-04-2013-0053

Luthans, F., Rhee, S., Luthans, B. C., \& Avey, J. B. (2008). Impact of behavioral performance management in a Korean application. Organization Development Journal, 29, 427-443. doi:10.1108/01437730810887030

Lutz, S. (Ed.). (1989). Respectfully quoted: A dictionary of quotations requested from the Congressional Research Service. Washington, DC: Library of Congress.

Marshall, C., \& Rossman, G. (2016). Designing qualitative research (6th ed.). Thousand Oaks, CA: Sage.

Matviuk, S. (2010). A correlational study of culture and leadership expectations in a Mexican manufacturing plant. The Business Review, Cambridge, 15, 14-19. 
Meadors, G. M. (2010). Healthcare reform: Regulations issued on early compliance requirements. The Journal of Medical Practice Management, 26, 163-165. Retrieved from http://www.greenbranch.com/article_872_The-Journal-of-Medical-Practice-Management.cfm

Morey, N. C., \& Luthans, F. (2013). Anthropology: the forgotten behavioral science in management history. Journal of Organizational Ethnography, 2, 82-91. doi:10.1108/JOE-04-2013-0007

Murphy, P. J., Cooke, R. A., \& Lopez, Y. (2013). Firm culture and performance: Intensity's effects and limits. Management Decision, 51, 661-679. doi:10.1108/00251741311309715

Müller, R., Spang, K., \& Ozcan, S. (2008). Cultural differences in decision making in project teams. International Journal of Managing Projects in Business, 2, 70-93. doi:10.1108/17538370910930527

Naor, M., Linderman, K., \& Schroeder, R. (2010). The globalization of operations in Eastern and Western countries: Unpacking the relationship between national and organization culture and its impact on manufacturing performance. Journal of Operations Management, 28, 194205. doi:10.1016/j.jom.2009.11.001

Narasimhan, R., Krull, T. J., \& Nahm, A. (2012). Alternative relationships among integrative beliefs, time-based manufacturing and performance. International Journal of Operations \& Production Management, 32, 496-524. doi:10.1108/01443571211223112

Nnadi, I. (2013). Son preference-a violation of women's human rights: A case study of Igbo custom in Nigeria. Journal of Politics and Law, 6, 134-141. Retrieved from http://ccsenet.org/journal/index.php/jpl/article/view/25154

Palombo, V. J. (2013). Exploring turnaround strategies for small machine shops (doctoral dissertation). Retrieved from ProQuest Dissertations and Thesis database. (UMI No. 3602392)

Peterson, T. O., \& Van Fleet, D. D. (2004). The ongoing legacy of R. L. Katz: An updated typology of management skills. Management Decision, 42, 1297-1308. doi:10.1108/00251740410568980

Prewitt, J., Weil, R., \& McClure, A. (2011). Developing leadership in global and multi-cultural organizations. International Journal of Business and Social Science, 2, 13-20.

Robbins, S. P., \& Judge, T. A. (2014). Organizational behavior (16th ed.). Upper Saddle, NJ: Prentice Hall.

Rockstuhl, T., Dulebohn, J. H., Ang, S., \& Shore, L. M. (2012). Leader-member exchange (LMX) and culture: A meta-analysis of correlates of LMX across 23 countries. Journal of Applied Psychology, 97, 1097-1130. doi:10.1037/a0029978

Söderholm, P., \& Norrbin, P. (2013). Risk-based dependability approach to maintenance performance measurement. Journal of Quality in Maintenance Engineering, 19, 316-329. doi:10.1108/JQME-05-2013-0023

Sultana, M. A., Rashid, M., Mohiuddin, M., \& Huda, M. (2013). Cross-cultural management and organizational performance: A content analysis perspective. International Journal of Business \& Management Studies, 8, 133-146. doi:10.5539/ijbm.v8n8p133

Uddin, M. J., Luva, R. H., \& Hossian, S. M. M. (2013). Impact of organizational culture on employee performance and productivity: A case study of telecommunication sector in Bangladesh. International Journal of Business and Management, 8, 63-77. doi:10.5539/ijbm.v8n2p63

Weadick, T., (2005). All the world's a stage. The Safety \& Health Practitioner, 23, 10-12. 
Voegtlin, C., Patzer, M., \& Scherer, A. (2012). Responsible leadership in global business: A new approach to leadership and its multi-level outcomes. Journal of Business Ethics, 105, 1-16. doi:10.1007/s10551-01100952-4

Yafang, T. (2011). Relationship between organizational culture, leadership behavior and job satisfaction. BMC Health Services Research, 11, 98-106. doi:10.1186/1472-6963-11-98

The Journal of Social Change, sponsored by Walden University, welcomes manuscripts focusing on interdisciplinary research in social change that improves the human condition and moves people, groups, organizations, cultures, and society toward a more positive future.

Walden University Publishing: http://www.publishing.waldenu.edu 